\title{
Optimization of Hole Cleaning and Cuttings Removal in High Inclined Till Horizontal Well
}

\author{
Karrar Ahmed Mohammed and Ayad A. Al-Haleem
}

Engineering College-Baghdad University

\begin{abstract}
The goal of this experimental study is to determine the effects of different parameters (Flow rate, cuttings density, cuttings size, and hole inclination degree) on hole cleaning efficiency. Freshwater was used as a drilling fluid in this experiment. The experiments were conducted by using flow loop consist of approximately $14 \mathrm{~m}(46 \mathrm{ft})$ long with transparent glass test section of $3 \mathrm{~m}(9.84 \mathrm{ft}$.) long with 4 inches $(101.6 \mathrm{~mm}) \mathrm{ID}$, the inner metal drill pipe with 2 inches $(50.8 \mathrm{~mm})$ OD settled with eccentric position positive 0.5 . The results obtained from this study show that the hole cleanings efficiency become better with high flow rate ( $21 \mathrm{~m} 3 / \mathrm{hr})$ and it increase as the hole inclination angles increased from 60 to 90 degree due to dominated of the rolling force. The cuttings size has negative influence on cuttings recovered as size increased and that is true for all cuttings specific gravity due to direct effect of the cuttings size and density on the gravity force which work against lifting force. The increasing of hole inclination angle above 60 degree will affect positively on cuttings removal efficiency.
\end{abstract}

Keywords: hole cleaning, high deviated well, horizontal well

Received on 04/11/2018, Accepted on 18/12/2018, published on 30/03/2020

https://doi.org/10.31699/IJCPE.2020.1.9

\section{1- Introduction}

Many of directional wells have been drilled around the world in the last few years. Directional well can be used effectively in the following application [1]:

1- In naturally fractured reservoirs because it is the best choice to drill a directional well with (90 degree angle) to intersect fractures and drain them effectively.

2- In reservoirs with water and gas conning.

3- It can be used in low and high permeability, so it is better to be used in gas production.

4- In EOR applications, especially in thermal EOR.

5- Drilling into the reservoir where vertical access is difficult or not possible.

6- Drilling a relief well, etc.

A lot of variables play an important role in hole cleaning and cuttings transportation such as inclination degree of the well, angle, the inner diameter of hole and the outer diameter of drill pipe, drill pipe rotation speed, eccentricity of drill pipe in wellbore, rate of penetration (ROP), size of cuttings, bed porosity, drilling fluids features such as flow rate and velocity, regime of the flow, and mud rheology [2].

For this Purpose, numerous researchers work on cutting transportation Error! Reference source not found.,
Error! Reference source not found., Error! Reference source not found.

Different branches have been studied by various researchers in dealing with cuttings removal difficulty issues with the drilling process parameters have been mistakenly applied, so it is very necessary to recap the drilling parameters to three groups according to the ability of direct controlling these parameters or not, these groups are [6]:

1- Input parameters (effectiveness parameters) such as mud weight, hook load, flow rate, mud type, hole angle, hole size, rotary speed, bit type, lithology.

2- Output parameters (directly affected parameters) such as effective circulating density (ECD), CSPP, torque, $\mathrm{P} / \mathrm{U}$ weight, rotated string weight, cutting the returned rate on shale shaker, returned mud density, rate of penetration.

3- Inner state (results due to change in input parameters) such as pipe eccentricity, cuttings size, the regime of the flow, height of the cuttings bed, annular cuttings concentration, weight on bit (W.O.B). 


\section{2- Experimental Work}

\subsection{Cuttings Transport Flow Loop Design}

In order to conduct the experimental program, the cuttings transport flow loop was built to investigate the effect of different parameters on hole cleaning. A schematic diagram and picture of the flow loop have been shown in Fig. 1.

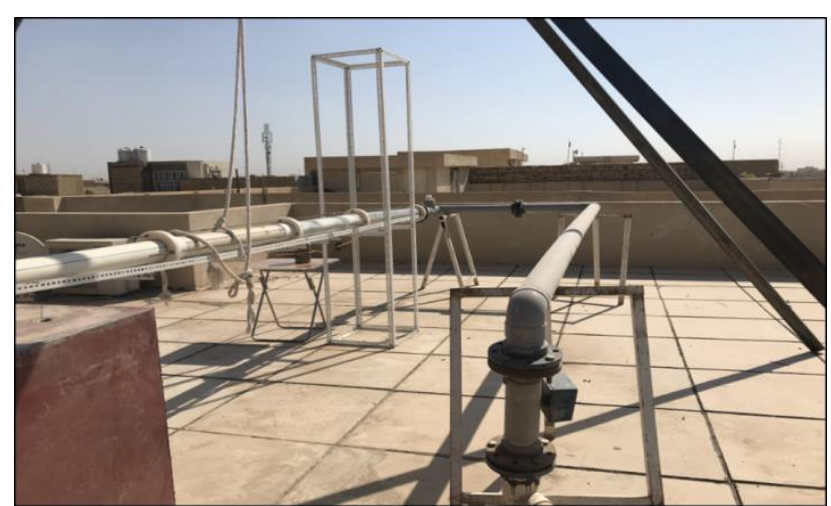

(a)

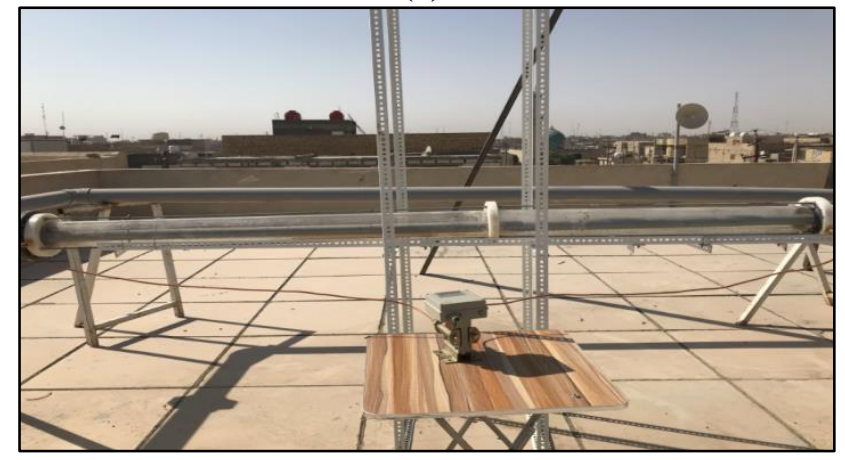

(b)

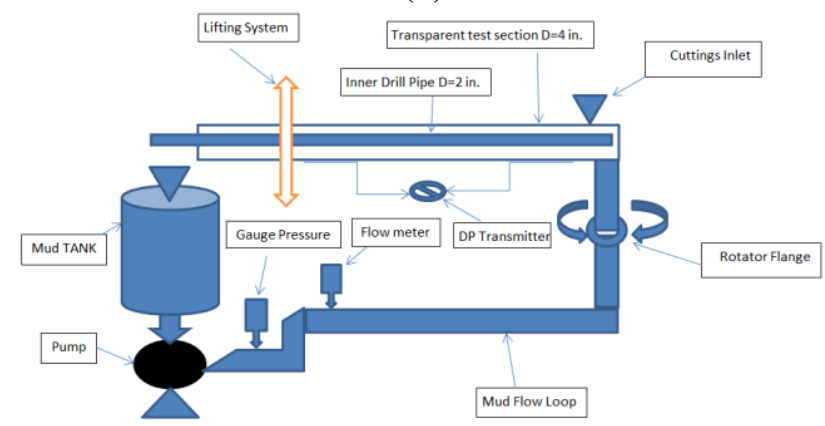

(c)

Fig. 1. a. Cuttings transport flow loop, b. Cuttings transport flow loop, c. Cuttings transport flow loop (schematic diagram)

Flow loop specially designed to permit the change in the inclination degree of the test section with various parameters used in this experiment. The experiments were conducted by using flow loop consist of approximately 14 $\mathrm{m}(46 \mathrm{ft})$ long with a transparent glass test section of $3 \mathrm{~m}$ (9.84 ft.) long with 4 inches $(101.6 \mathrm{~mm})$ ID, the inner metal drill pipe with 2 inches $(50.8 \mathrm{~mm})$ OD settled with eccentric position positive 0.5 .

The fluid feed line made from PVC with 4 inch ID as long of $8 \mathrm{~m}$ and the main function is to transport the drilling fluid to test section and in position, while it near the inlet of the test section the cuttings are injected to flow to pass as two phases(cuttings-drilling fluid) during the test section. The test section was attached to the feed line through the movable joint in order to change the degree of test section inclination. All experiments were conducted under ambient temperature and atmospheric pressure conditions.

The drilling fluid is mixed in a mixing tank of $1 \mathrm{~m} 3$ (1000 liters) where the liquid is supply to the feed line.

Table 1 summarized the values of the variables used in this experiment

Table 1. Range of variables used in the experiment

\begin{tabular}{ll}
\hline Parameter & Range of value \\
\hline Annulus length, m (ft) & $5 \mathrm{~m}(16.4 \mathrm{ft})$ \\
Annulus OD X ID, mm & $101.6 \mathrm{~mm} \times 50.8 \mathrm{~mm},(4$ \\
(in) & in.x2 in.) \\
Annulus inclination, & $90^{\circ}, 80^{\circ}, 70^{\circ}, 60^{\circ}$ \\
degree & $15-21 \mathrm{~m}^{3} / \mathrm{hr} .(66-92.5$ \\
Flow rate, $\mathrm{m}^{3} / \mathrm{hr} .(\mathrm{GPM})$ & $\mathrm{GPM})$ \\
ROP, m./hr. (ft./hr.) & $1 \mathrm{~m} / \mathrm{hr} .(3.28 \mathrm{ft} . / \mathrm{hr})$. \\
Inner pipe eccentricity & $0.5 \quad 1.7$ and $3.35 \mathrm{~mm} \mathrm{(0.0661}$ \\
Particle size, mm (in.) & and $0.132 \mathrm{in})$. \\
& Limestone (2.7) and \\
Particle specific gravity & Limestone-Dolomite (2.6) \\
Drilling fluid used & Water \\
\hline
\end{tabular}

\subsection{Experimental procedure}

The cuttings amount that should be injected to each test simulated ROP was calculated to both kinds of cuttings used in these experiments, the procedure for calculating was as follow:

Assuming cutting ROP $=1 \mathrm{~m} / \mathrm{hr}$.

Cuttings volume $=$ area of annulus $*$ rate of penetration $*$ solid fraction

Cutting V. $=\pi \mathrm{r}^{2} * \mathrm{ROP} *(1-\phi)$

$$
\begin{aligned}
& =Л(0.05)^{2} * 0.0166 *(1-0.22) \\
& =0.000101 \mathrm{~m}^{3} / \mathrm{hr} .
\end{aligned}
$$

For Limestone cutting multiply by specific gravity 2.4 $\mathrm{gm} / \mathrm{cc}$

Cutting injection rate $=0.000101 * 2.4 * 1000000=$ $242.4 \mathrm{gm} / \mathrm{min}$.

For Limestone-Dolomite cutting multiply by Specific gravity $2.6 \mathrm{gm} / \mathrm{cc}$

Cutting injection rate $=0.000101 * 2.6 * 1000000=262.6$ $\mathrm{gm} / \mathrm{min}$. 
A brief description of the experimental work steps followed during the execution of the experiments is presented as follow:

1- Adjusted degree of inclination (90 - $80-70-60)$ degree.

2- Adjusted all other factors involved in these experiments:

- Cuttings type Limestone and limestone-dolomite.

- Cuttings size two ranges (1.7 and $3.36 \mathrm{~mm}$ ).

- Annular velocity two ranges (0.685 and 1.051 $\mathrm{m} / \mathrm{sec}$.).

3- Start the pump and adjust the liquid flow rate (65 and 100 GPM).

4- Wait for flow pattern stabilization.

5- Inject the cuttings that simulated the desired ROP.

6- Collect the outlet cutting from the sieve screen, to calculate the cuttings recovered.

7- Circulate with High flow rate to clean the annulus from remain cuttings after test.

8- Stop the pump.

\section{3- Results and Discussion}

Table 2 shows the experimental results of cuttings recovered $\mathrm{CR} \%$ for different values of flow rate with different values of parameters ( hole inclination angle, cuttings type and size).

Table 2. Cuttings recovered percent for different parameters

\begin{tabular}{|c|c|c|c|c|c|c|c|}
\hline $\begin{array}{l}\text { Flow } \\
\text { Rate } \\
\mathrm{m}^{3} / \mathrm{hr}\end{array}$ & Velocity ft./sec & Angle & Cuttings Type & Cutting Size & $\Delta \mathrm{P} \mathrm{m}$ bar & $\begin{array}{l}\text { Cuttings } \\
\text { transported gm }\end{array}$ & $\mathrm{CR} \%$ \\
\hline 15 & 2.248 & 90 & Lime & 1.7 & 13 & 25 & 10.29 \\
\hline 15 & 2.248 & 90 & Lime & 3.35 & 13.5 & 8 & 3.29 \\
\hline 15 & 2.248 & 90 & Lime-Dolo & 1.7 & 13 & 27 & 10.27 \\
\hline 15 & 2.248 & 90 & Lime-Dolo & 3.35 & 14 & 7 & 2.66 \\
\hline 15 & 2.248 & 80 & Lime & 1.7 & - & 17 & 7.00 \\
\hline 15 & 2.248 & 80 & Lime & 3.35 & - & 6 & 2.47 \\
\hline 15 & 2.248 & 80 & Lime-Dolo & 1.7 & - & 8 & 3.04 \\
\hline 15 & 2.248 & 80 & Lime-Dolo & 3.35 & - & 7 & 2.66 \\
\hline 15 & 2.248 & 70 & Lime & 1.7 & - & 14 & 5.76 \\
\hline 15 & 2.248 & 70 & Lime & 3.35 & - & 10 & 4.12 \\
\hline 15 & 2.248 & 70 & Lime-Dolo & 1.7 & - & 20 & 7.60 \\
\hline 15 & 2.248 & 70 & Lime-Dolo & 3.35 & - & 8 & 3.04 \\
\hline 15 & 2.248 & 60 & Lime & 1.7 & - & 14 & 5.76 \\
\hline 15 & 2.248 & 60 & Lime & 3.35 & - & 12 & 4.94 \\
\hline 15 & 2.248 & 60 & Lime-Dolo & 1.7 & - & 20 & 7.60 \\
\hline 15 & 2.248 & 60 & Lime-Dolo & 3.35 & - & 6 & 2.28 \\
\hline 21 & 3.447 & 90 & Lime & 1.7 & 22 & 200 & 82.30 \\
\hline 21 & 3.447 & 90 & Lime & 3.35 & 22 & 200 & 82.30 \\
\hline 21 & 3.447 & 90 & Lime-Dolo & 1.7 & 25 & 180 & 68.44 \\
\hline 21 & 3.447 & 90 & Lime-Dolo & 3.35 & 25.5 & 145 & 55.13 \\
\hline 21 & 3.447 & 80 & Lime & 1.7 & - & 201 & 82.72 \\
\hline 21 & 3.447 & 80 & Lime & 3.35 & - & 180 & 74.07 \\
\hline 21 & 3.447 & 80 & Lime-Dolo & 1.7 & - & 201 & 76.43 \\
\hline 21 & 3.447 & 80 & Lime-Dolo & 3.35 & - & 91 & 34.60 \\
\hline 21 & 3.447 & 70 & Lime & 1.7 & - & 200 & 82.30 \\
\hline 21 & 3.447 & 70 & Lime & 3.35 & - & 170 & 69.96 \\
\hline 21 & 3.447 & 70 & Lime-Dolo & 1.7 & - & 120 & 45.63 \\
\hline 21 & 3.447 & 70 & Lime-Dolo & 3.35 & - & 90 & 34.22 \\
\hline 21 & 3.447 & 60 & Lime & 1.7 & - & 170 & 69.96 \\
\hline 21 & 3.447 & 60 & Lime & 3.35 & - & 150 & 61.73 \\
\hline 21 & 3.447 & 60 & Lime-Dolo & 1.7 & - & 100 & 38.02 \\
\hline 21 & 3.447 & 60 & Lime-Dolo & 3.35 & - & 95 & 36.12 \\
\hline
\end{tabular}

3.1. Effect of Superficial Velocity on Cuttings Delivered Concentration

The importance of getting turbulent flow is very necessary to agitate the cuttings bed and get the cuttings transported mechanisms to be converted to suspension mechanisms (especially in hole inclination above 60 degrees where the stationary/moving bed mechanisms are

In high inclined wellbore, the engineers should design drilling fluids that able to decrease the slip velocity with a flow profile that maximizes the velocity under the eccentric drill pipe.

The results for this experiment show that the flow rate is the most effective parameter that has a direct influence on cuttings removal even with a change in the value of all other parameters, as shown in Fig. 2.

It should be mentioned that the increment in flow rate indicates more pressure drop but after some points, the pressure drop starts to decrease due to reduction in the cuttings bed and by means increasing the area open for flow [7], [8]. dominated). 


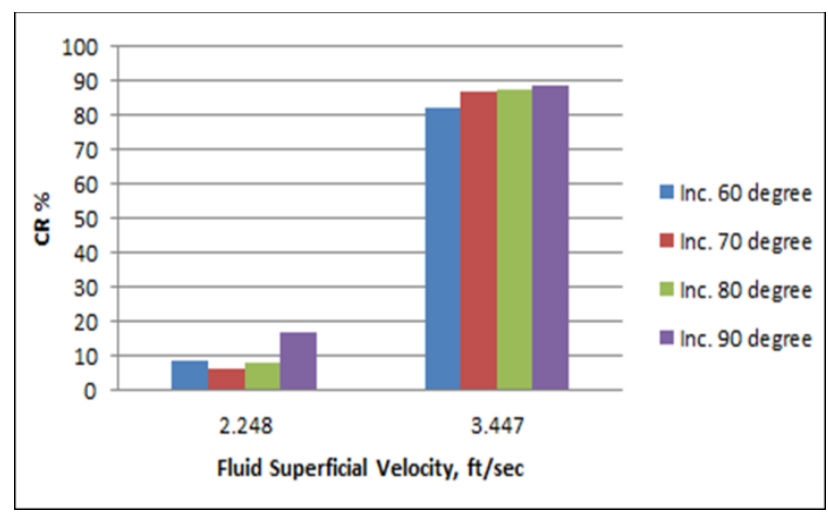

Fig. 2. Fluid superficial velocity, ft./sec Vs. CR\% with 1.7 mm limestone cuttings

\subsection{Hole Inclination Angle Effect on Cuttings Delivered Concentration}

The hole inclination angle of the wellbore is an important parameter that effect on the hole cleaning and all other parameters should maintain according to the degree of inclination, that because hole inclination effect on phenomena of cuttings flows while drilling fluids and also affect and change the percent that the forces influences on the particles movements. Previous studies have established the majority of the effect of hole inclination on cuttings transport and show that the toughest section for hole cleaning is the middle section (40-60 degree) due to a combination of beds avalanching, Boycott settling, and an asymmetrical flow profile [9]. Angles above 60 degree it's also difficult to be cleaned due to the dominated of the radial components of the slip velocity and that help to build a more thick and tough cuttings bed. In that case, the attention should be paid to prevent the cuttings bed from forming and convert the cuttings transportation phenomena to suspension mechanisms, and that can be achieved by increasing the flow rate to get as can as possible a turbulent flow that can agitate the bed and transport the cuttings in suspension and that can be seen clearly as a results of this experiments in Fig. 3. These figures the cuttings recovered percent is plotted against the inclination angle of the well with different flow rates and cuttings size, and for fixed cuttings specific gravity.

\subsection{Cuttings Density and Size Effect on Delivered} Cuttings Concentration

Cuttings density has a direct influence on the cuttings slip velocity and that influence dominated clearly in nearvertical well angles but for the horizontal and nearhorizontal well the influence of the cuttings density has a direct influence on the gravity force and by means on the lifting/sliding force of the cuttings bed and that clearly observed in Fig. 4.
The size of the drilled cuttings also has a big influence on the bed height and cuttings recovered percent since the size of that large cutting has a tendency to form bed and roll along the low side of the wellbore, as proved in previous studies [10], [11]. The cuttings with large size at high angles $\left(65^{\circ}\right.$ and more) tend to form stationary bed at the low side of the well, in that case, and with the absence of the pipe rotation, only the high flow rate can disturb the bed and achieve a homogeneous suspension, as shown in Fig. 5.

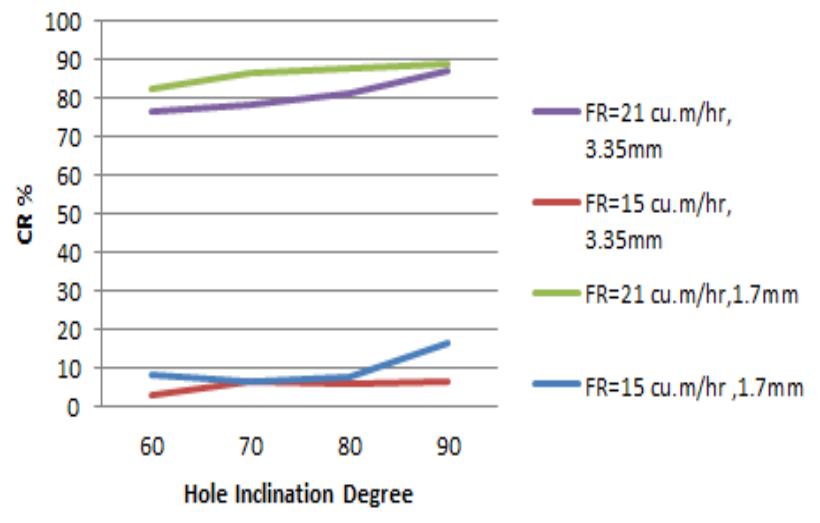

Fig. 3. Hole inclination angle Vs. CR \% for limestone cuttings type

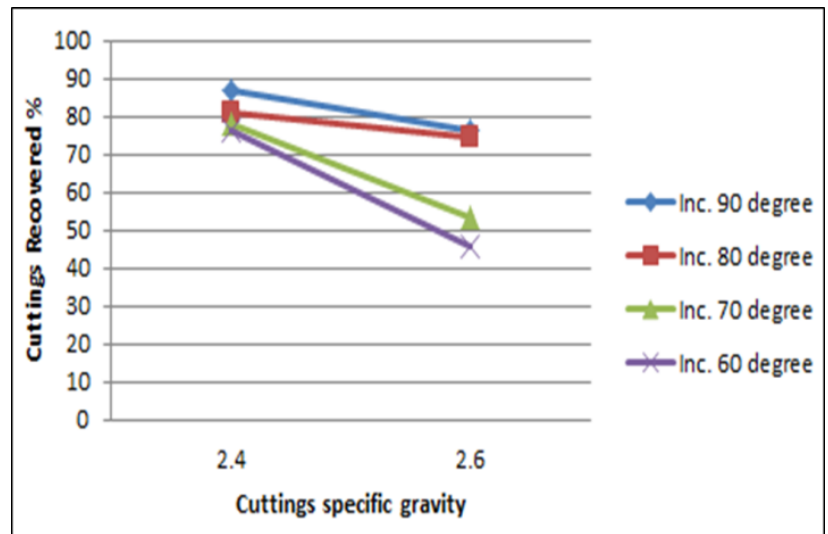

Fig. 4. Cuttings S.G. Vs. CR\% for $3.35 \mathrm{~mm}$ in size with $\mathrm{FR}=21 \mathrm{~m}^{3} / \mathrm{hr}$

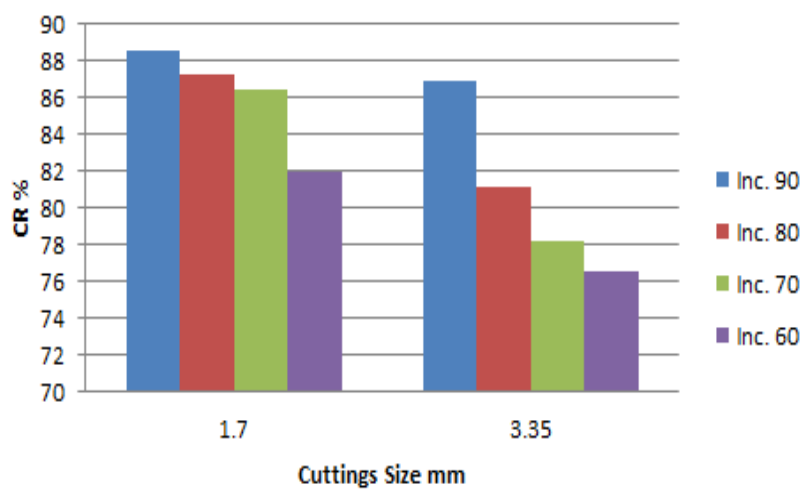

Fig. 5. CR\% Vs. cuttings size, $\mathrm{mm}$ for limestone with 0.8 $\mathrm{kg} / \mathrm{m}^{3}$ polymer and $\mathrm{FR}=21 \mathrm{~m}^{3} / \mathrm{hr}$ 


\section{4- Conclusions}

1- Experimental results for different hole inclinations angles, different cuttings type, and sizes with different drilling fluid types showed that the fluid velocity is the most effective parameter that can improve hole cleaning.

2- In high deviated well (more than $60^{\circ}$ ) the cuttings density effect has a direct influence on the gravity force that effects on the cuttings, and that means more cuttings deposition will occur in the annulus as the density increased.

3- The results indicate that cuttings size also influences on hole cleaning efficiency. For different hole inclinations and flow rates with different drilling fluids type the increment in cuttings size will affect negatively the efficiency of hole cleanings, the size of the small cutting is easier to carry out of the annulus.

4- Hole inclination angles effect the cuttings delivered concentration by changing the percent of the effect of the force on the particles inside the wellbore. The increase in the degree of inclination above $60^{\circ}$ has less effect on hole cleaning and that proved by the results of this experiment.

\section{References}

[1] S. Okrajni and J. Azar, Jan. 1986, "The Effects of Mud Rheology on Annular Hole Cleaning in Directional Wells," SPE Drilling Engineering, vol. 1, no. 04, pp. 297-308.

[2] D. Power, C. Hight, D. Weisinger, and C. Rimer, 2000, "Drilling Practices and Sweep Selection for Efficient Hole Cleaning in Deviated Wellbores" IADC/SPE Asia Pacific Drilling Technology.

[3] F. H. M. Al-Mahdawi and K. Saad, "Enhancement of Drilling Fluid Properties Using Nanoparticles", ijcpe, vol. 19, no. 2, pp. 21-26, Jun. 2018.

[4] A. Assi, "Potato Starch for Enhancing the Properties of the Drilling Fluids", ijcpe, vol. 19, no. 3, pp. 33-40, Sep. 2018.

[5] H. Neamah and A. A.Alrazzaq, "Torque and Drag Forces Problems in Highly Deviated Oil Well", ijcpe, vol. 19, no. 3, pp. 19-31, Sep. 2018.

[6] J. D. Ytrehus, I. M. Carlsen, J. C. Melchiorsen, J. Abdollahi, P. Skalle, A. Saasen, M. A. Taghipour, A. Reyes, N. V. D. T. Opedal, and B. Lund, 2013, "Experimental Study Of Friction And Cutting Transport In Non-Circular Borehole Geometry" SPE/IADC Middle East Drilling Technology Conference \& Exhibition.

[7] J. Ford, J. Peden, M. Oyeneyin, E. Gao, and R. Zarrough, 1990, "Experimental Investigation of Drilled Cuttings Transport in Inclined Boreholes" Proceedings of SPE Annual Technical Conference and Exhibition, pp. 197-206.
[8] J. Li and S. Walker, May 2001, "Sensitivity Analysis of Hole Cleaning Parameters in Directional Wells" SPE/ICoTA Coiled Tubing Roundtable, pp. 356-363.

[9] J. Mitchell, 2001, "Trouble-free drilling", Pre-edition., vol. 1. Woodlands, TX: Drilbert Engineering.

[10] Nada Sabah, 2007, "Experimental Study of Cuttings Transportation in Horizontal wells", Ph.D. dissertation, University of Baghdad, College of engineering.

[11] Raed Hamed, 2017, "Experimental Study of Hole Cleaning in Directional Wells" M.S. Thesis, College of Engineering, University of Baghdad.

\section{Nomenclatures}

RPM Rotation per minute.

ID, OD Inner and outer diameter, mm.

H.P. $\quad$ Horse power.

FR Flow rate, $\mathrm{m}^{3} / \mathrm{hr}$.

ECD Equivalent circulation density, ppg.

CSPP Casing shut in pipe pressure, psi.

W.O.B. Weight on bit, ton.

ROP Rate of penetration, $\mathrm{m} / \mathrm{hr}$. 


\section{أمثلية تنظيف البئر و رفع القطع الصخرية في الابار الافقية و شديدة الميلان \\ كرار أحمد محمد و اياد عبد الحيم عبد الرزلق}

كلبة المندسة-جامعة بغداد

الخلاصة

الهدف من هذه الدراسة العملية هو لاستبيان نأثير مختلف العوامل (تدفق سائل الحفر , كثافة وحجم القطع

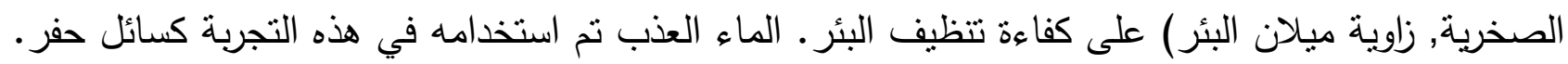

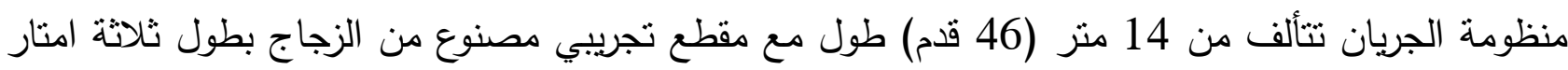

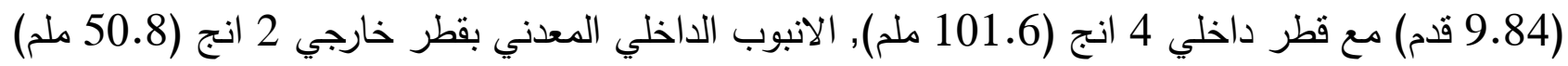
متموضع بلامركزية مقدارها موجب 0.50. النتائج المستحصلة من هذه التجربة بينت التبوبر ان كفاءة تتظيف البئر تصبح افضل مع زيادة تدفق سائل الحفر (21 منز مكعب لكل ساعة) وتزدداد الكفاءة مع زيادة درجة ميلان

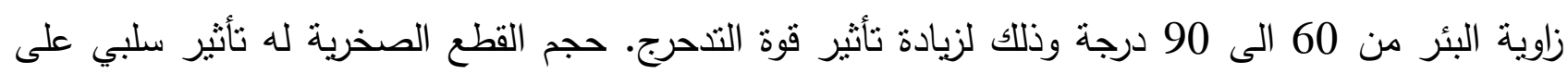
حجم القطع الصخرية المستحصلة وهذا ينطبق على جميع كثافات القطع الصخرية المستخدمة وذللك لتأثيرها المباشر على قوة الجاذبية الارضية للقطع المحفورة والتي تعمل بالضد من قوة الرفع. الزيادة في زاوية ميلان

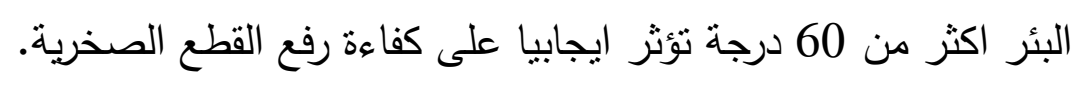

الكلمات الدالة: تتظيف الحفر ، انحراف عالي، بئر أفقي 